\title{
Studies on physiological parameters of Alternaria alternata (Fr) keissler-The incitant of leaf blight of groundnut
}

\section{S.L. KANTWA ${ }^{1}$, K.S. SHEKHAWAT ${ }^{1}$ AND J.P. TETARWAL*}

Department of Plant Pathology, Rajasthan College of Agriculture, Maharana Pratap University of Agriculture and Technology, UDAIPUR (RAJASTHAN) INDIA

${ }^{1}$ Department of Plant Pathology, S.K.N. College of Agriculture (S.K.R.A.U.), JOBNER (RAJASTHAN) INDIA

\section{ARITCLE INFO}

Received : 24.02 .2015

Revised : 05.09 .2015

Accepted : 20.09 .2015

\section{KEY WORDS :}

Alternaria alternata, Physiological parameters, Leaf blight, Groundnut

*Corresponding author:

Email: jp.tetarwall@gmail.com

\begin{abstract}
Leaf blight caused by Alternaria alternata (Fr) Keissler was observed on leaves of groundnut. Out of six different solid and liquid media and different levels of temperature, relative humidity and $\mathrm{pH}$ tested for mycelial growth and sporulation of fungus, the maximum mycelial growth and sporulation were observed on potato dextrose agar at $25^{\circ} \mathrm{C}$ temperature, 100 per cent relative humidity and $\mathrm{pH} 6.5$.
\end{abstract}

How to view point the article : Kantwa, S.L., Shekhawat, K.S. and Tetarwal, J.P. (2015). Studies on physiological parameters of Alternaria alternata (Fr) keissler-The incitant of leaf blight of groundnut. Internat. J. Plant Protec., 8(2) : 359-363. 